\title{
Rancang Bangun Prototype Object Counter Berbasis Automated System untuk Mengurangi Jumlah Infeksi Covid-19 pada Hotel Siti
}

\author{
Arif Fadli $^{1}$, Subhiyanto ${ }^{2}$
}

\begin{abstract}
Microcontroller is a hardware device in which there is a processor, input and output, RAM, ROM, System Bus, Control Unit, Shift Register and Arithmetic Logic Unit. Microcontroller requires input components such as light sensors $(L D R)$, temperature sensors, proximity sensors (HCSR) as a trigger to the microcontroller to activate output components as indicators such as leds, buzzers, servo motors and others. Currently, the world, especially in Indonesia, is experiencing a COVID-19 virus pandemic from the beginning of 2020 so the government has made several policies to deal with this covid-19 virus, one of which is by limiting the maximum number that must be in the room to $50 \%$ in several sectors such as offices., restaurants and others. To support the government's policy, at Hotel Siti Tangerang, an embedded system was created to count the number of objects entering the hotel by using infrared sensors as input. So when the number of objectsat Hotel Siti Tangerang has reached the maximum limit, the hotel door cannot be opened, the buzzer sounds and the LED lights up as an indicator that the room is full. With the creation of this embedded system, it is hoped that this will be a preventive measure in dealing with the Covid-19 virus and the percentage of peopleinfected with the Covid-19 virus in Indonesia will decrease.
\end{abstract}

Intisari-Mikrokontroller merupakan sebuah perangkat keras yang didalamnya terdapat sebuah processor, input dan output, RAM, ROM, System Bus, Contol Unit, Shift Register dan Aritmatic Logic Unit. Mikrokontroller membutuhkan komponen inputseperti sensor cahaya (LDR), sensor suhu, sensor jarak (HCSR) sebagai trigger kepada mikrokontroller untuk mengaktifkan komponen output sebagai indikator seperti led, buzzer, motor servo dan lainlain. Saat ini, di dunia khususnya di Indonesia sedang mengalami pandemic virus covid-19 dari awal tahun 2020 sehingga pemerintah membuat beberapa kebijakan untuk menangani virus covid- 19 ini, salah satunya dengan membatasi jumlah maksimal yang harus berada di ruangan menjadi $50 \%$ dibeberapa sektor seperti perkantoran, restoran dan lain-lain. Untuk mendukung kebijakan pemerintah tersebut, maka di Hotel Siti Tangerang dibuat sebuah embedded system untuk menghitung jumlah object yang memasuki hotel dengan memanfaatkan sensor infrared sebagai input. Sehingga ketika jumlah object di Hotel Siti Tangerang sudah mencapai batas maksimum, maka pintu hotel tidak dapat terbuka, buzzer berbunyi dan lampu led menyala sebagai indikator ruangan sudah penuh. Dengan dibuatnya embedded system ini diharapkan sebagai tindakan preventif dalam menangani virus covid-19 dan presentase jumlah orang yang terinfeksi virus covid-19 di Indonesia semakin menurun.

Kata Kunci-Covid-19, Mikrokontroler, Automated System, Physical Distancing.

\section{PENDAHULUAN}

${ }^{1,2}$ Jurusan Teknik Informatika, STMIK Antar Bangsa, Jl. HOS Cokroaminoto, Kawasan Bisnis CBD Ciledug,Blok A5 No 29-36, Karang Tengah, Tangerang 15157; Tlp:089635845819, 087888393980; $\quad$ E-mail: $\quad$ ariffadly789@gmail.com, subhiyanto.bian@gmail.com
Pada Akhir tahun 2020 Kota Wuhan di China mengidentifikasi adanya virus Covid-19 dan melaporkan hal tersebut secara resmi kepada Organisasi kesehatan Dunia (WHO). Daud, dkk (2020:6) menjelaskan dalam buku yang dia tulis : "Coronavirus merupakan keluarga besar virus yang menyebabkan penyakit pada manusia dan hewan. Pada manusia biasanya menyebabkan penyakit infeksi saluran pernapasan, mulai flu biasa hingga penyakit serius seperti Middle East Respiratory Syndrome (MERS) dan Sindrom Pernafasan Akut Berat/ Severe Acute Respiratory Syndrome (SARS) [1].

Coronavirus jenis baru yang ditemukan pada manusia sejak kejadian luar biasa muncul di Wuhan Cina, pada Desember 2019, kemudian diberi nama Severe Acute Respiratory Svndrome Coronavirus 2 (SARS-COV), dan menyebabkan penyakit Coronavirus Disease-2019 (Covid 19).”. Pada tanggal 2 Maret 2020 Presiden Indonesia bapak Joko Widodo dan didampingi oleh Menteri Kesehatan saat itu Terawan Agus Putranto secara resmi mengumumkan bahwa dua Warga Negara Indonesia (WNI) telah terpapar Virus Covid-19. Menurut Menkes Terawan kedua WNI tersebut terpapar Virus Covid-19 dari rekannya yang berkewarganegaraan Jepang. Mereka tertular setelah bertemu disebuah acara [2].

Sampai saat ini, sejak pertama kali pengumuman covid-19, Indonesia sudah hampir dua tahun mengalamai pandemic virus covid-19. Sebagai bentuk upaya untuk mengurangi angka penurunan orang yang terpapar virus covid-19, pemerintah mengeluarkan beberapa kebijakan protokol kesehatan, salah satunya adalah membatasi jumlah maksimum yang harus ada didalam satu ruangan menjadi 50\% dari jumlah maksimal. Kebijakan ini berlaku bagi semua aspek seperti perkantoran, mall, restoran dan sebagainya [3].

Dalam Keputusan Menteri Kesehatan Republik Indonesia No. 01.07/MENKES/ 382/2020 pemerintah juga menghimbau agar setiap hotel dapat memperhitungkan jaga jarak minimal 1 meter antar tamu dan antar karyawan. Hal ini dapat dilakukan dengan menghitung kembali jumlah undangan, pembuatan lay out ruangan, membagi acara menjadi beberapa sesi, membuat sistem antrian, dan lain sebagainya [4].

Dengan adanya peraturan pemerintah tersebut dalam hal ini social distancing dan physical distancing, maka kapasitas dalam sebuah ruanganpun harus dikurangi dari kapasitas aslinya agar tetap terciptanya jarak antar pengunjung dalam sebuah ruangan. Oleh sebab itu setiap tempat yang sering dikunjungi oleh banyak orang harus memiliki penghitungan yang tepat mengenai jumlah pengunjung yang datang agar dapat dibatasi jika sudah melebihi kapasitas seharusnya. Begitu juga dengan tempat penulis melakukan riset, yaitu Hotel Siti yang setiap harinya kedatangan tamu dari berbagai daerah. 
Selain melakukan pengecekan suhu, kapasitas pengunjung juga harus dibatasi agar tetap terciptanya physical distancing antar pengunjung.

Seiring perkembangan teknologi, kebijakan tersebut bisa dibuat sebuah automated system untuk menghitung jumlah objek yang ada didalam sebuah ruangan berbasis mikrokontroller, dalam hal ini Arduino Uno. Automated system ini dapat menghitung jumlah pengunjung dalam ruangan dengan akurasi tinggi serta dapat mengurangi resiko penularan antara staff hotel dan pengunjung, karena tugas dari staff hotel yang enjaga di pintu masuk dapat digantikan oleh automated system tersebut [5].

Adapun tujuan dilakukan penelitian ini adalah 1) Membantu kebijakan pemerintah terkait pembatasan jumlah maksimum didalam sebuah ruangan. 2) Membantu pengelola hotel dalam proses kontroling jumlah objek. 3) Implementasi disiplin ilmu yang penulis pelajari selama kuliah. 4) Untuk memberikan tambahan referensi belajar bagi para mahasiswa STMIK Antar Bangsa dalam hal pemanfaatan teknologi informasi, terutama dibidang mikrokontroller.

\section{TINJAUAN PUSTAKA}

\section{A. Prototype}

Dalam jurnalnya, Safira, dkk menjelaskan "Prototype didefinisikan sebagai satu versi dari sebuah sistem potensial yang memberikan ide bagi para pengembang dan calon pengguna, bagaimana sistem akan berfungsi dalam bentuk yang telah selesai" [6].

Dasar dari pemikiran ini adalah membuat prototype secepat mungkin, bahkan dalam waktu semalam, lalu memperoleh umpan balik dari pengguna yang akan memungkinkan prototype tersebut diperbaiki kembali dengan cepat. semua rancangan diagaram atau model yang dibuat tidak diharuskan telah sempurna dan final dalam pendekatan prototype. Tujuan utama dari penyiapan rancangan adalah sebagai alat bantu dalam memberi gambaran sistem seperti materi dan menu yang perlu dimasukkan dalam prototype yang akan dikembangkan. Setelah perancangan terbentuk, dilanjutkan dengan mulai mengembangkan prototype.

Metode prototype sesuai untuk menjelaskan kebutuhan pengguna secara lebih rinci karena pengguna sering mengalami kesulitan dalam penyampaian kebutuhannya secara detail tanpa melihat gambaran yang jelas. Untuk mengantisipasi agar proyek dapat berjalan sesuai dengan rencana, target waktu, dan biaya diawal, maka sebaiknya spesifikas kebutuhan sistem haru sudah disepakati terlebih dahulu oleh pengembang dengan pengguna dalam hal ini klien. Adapun tahapan-tahapannya metode prototype adalah sebagai berikut :

1. Mengidentifikasi pengguna. Pada tahap ini penulis mewawancarai pihak dari perusahaan/instansi untuk mengetahui mengenai masalah yang ada di perusahaan tersebut, kemudian mendapat ide untuk membuat sistem yang dibutuhkan.

2. Mengembangkan prototype. Membangun prototype dengan membuat perancangan sementara yang berfokus pada penyajian yaitu membuat input dan output.

3. Menentukan apakah prototype dapat diterima, melakukan evaluasi terhadap sistem yang dibangun penulis, apakah sistem sudah sesuai dengan yang diinginkan, jika iya maka akan dilakukan langkah selanjutnya yaitu mengkodekan sistem, jika idak, maka akan dilakukan revisi pada sistem yang telah dibangun.

4. Menggunakan prototype, prototype selesai menjadi sistem dan sistem siap digunakan

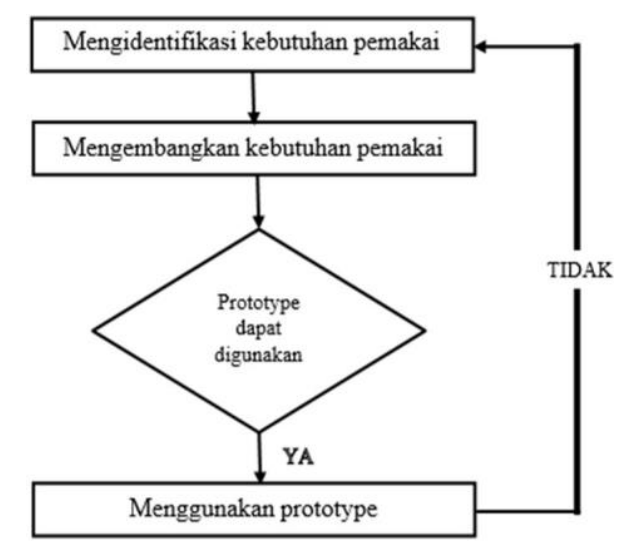

Source

https://ejournal.antarbangsa.ac.id/index.php/jti/article/view/345 Gambar II.1. Tahapan Prototype

\section{B. Mikrokontroler}

Mikrokontroler adalah salah satu dari bagian dasar dari suatu sistem komputer. Meskipun mempunyai bentuk yang jauh lebih kecil dari suatu komputer pribadi dan komputer mainframe, mikrokontroler dibangun dari elemen-elemendasar yang sama. Mikrokontroler tersusun dalam satu chipdimana prosesor, memori, dan I/O terintegrasi menjadi satu kesatuan kontrol sistem sehingga mikrokontroler dapat dikatakan sebagai komputer mini yang dapat bekerja secara inovatif sesuai dengan kebutuhan sistem. Sistem running bersifat berdiri sendiri tanpa tergantung dengan komputer sedangkan parameter komputer hanya digunakan untuk download perintah instruksi atau program. Langkah-langkah untuk download komputer dengan mikrokontroler sangat mudah digunakan karena tidak menggunakan banyak perintah. Pada mikrokontroler tersedia fasilitas tambahan untuk pengembangan memori dan I/O yang disesuaikan dengan kebutuhan sistem. Harga untuk memperoleh alat ini lebih murah dan mudah didapat [7].

\section{Arduino Uno}

Arduino Uno adalah board mikrokontroler berbasis ATmega328 (datasheet). Memiliki 14 pin input dari output digital dimana 6 pin input tersebut dapat digunakan sebagai output PWM dan 6 pin input analog, $16 \mathrm{MHz}$ osilator kristal, koneksi USB, jack power, ICSP header, dan tombol reset. Untuk mendukung mikrokontroler agar dapat digunakan, cukup hanya menghubungkan Board Arduino Uno ke komputer dengan menggunakan kabel USB atau listrikdengan AC yang-keadaptor-DC atau baterai untuk menjalankannya [8]. 


\section{METODE PENELITIAN}

A. Analisa Penelitian

1. Planning

Dalam tahap planning ini, penulis melakukan list komponen apa saja yang dibutuhkan untuk membuat prototype ini, dimulai dari bagian input, proses dan output. Kemudian setelah dilist, selanjutnya pembelian alat, perakitan alat sesuai rangkian yang telah dibuat dan terakhir pengujian prototype Object Counter.

2. Analisis

Dalam tahap analisis, penulis membutuhkan komponen dibagian input yaitu sensor infrared sebanyak 1 buah, dibagian proses membutuhkan Mikrokontroller Arduino Uno dan dibagian output membutuhkan LED 2 buah, Buzzer 1 buah, motor Servo 1 buah dan LCD Display 16x2 1 buah [9].

3. Desain

Dalam tahap desain prototype, penulis merancang desain sesuai dengan kontruksi yang ada di Hotel Siti Tangerang. Dibgaian bentuk gedung dan akan sedikit berbeda dibagian pintu masuk Hotel.

\section{Pengujian}

Dalam tahap pengujian ini, penulis melakukan pengujian pertama kali untuk setiap komponen yang digunakan. Dimulai dari bagian input memastikan sensor infared mampu membaca atau mendeteksi objek yang kemudian menghasilkan sebuah nilai high atau low sebagai trigger untuk mengaktifkan komponen output. Dibagian proses, penulis menguji mikrokontroller menggunakan script. examples yang ada di software Arduino IDE, yaitu Blinking Led sehingga dapat dipastikan mikrokontroller berfungsi dengan baik. Terakhir dibagian output penulis menguji dengan cara menghidupkan LED, menggerakkan motor servo, mengaktifkan buzzer dan Menampilkan informasi pada LCD display dengan coding sederhana sebelum digunakan.

5. Implementasi

Setelah tahap planning, analisis, desain, pengujian maka penulis melakukan tahap implementasi. Didalam tahap ini, penulis menghubungkan setiap komponen input, proses dan output sehingga saling terhubung satu sama lain sesuai dengan skema rangkaian yang telah dibuat. Kemudian membuat kontruksi sesuai pada tahap desain.

B. Metode Pengumpulan Data

1. Observasi

Melalui metode ini penulis melakukan observasi langsung di Hotel Siti terkait struktur bangunan dan keadaan pintu masuk.

2. Wawancara

Untuk mengetahui permasalahan yang dihadapi selama proses keluar masuknya objek kedalam hotel.

3. Studi Pustaka

Yaitu dengan mengumpulkan berbagai sumber referensi seperti buku, jurnal, artikel dan sumber lain untuk mendukung perancangan dan pembuatan prototype Object Counter ini.

\section{PEMBAHASAN DAN HASIL}

Perencanaan dan pembuatan smart home ini terdiri dari beberapa tahap, yaitu : 1) Pembuatan blok diagram, 2) Perencanaan catu daya, 3) Perencanaan input, 4) Perencanaan proses, 5) Perencanaan output, 6) Perencanaan Rangkaian keseluruhan, 7) Perancangan program, dan 8) Pengujian.

A. Blok Diagram

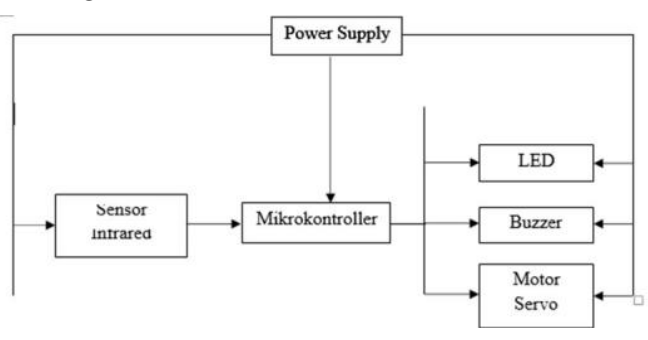

Sumber : Rangkaian Penelitian Gambar III.1. Blok Diagram

B. Perencanaan Catu Daya

Rangkaian power suply diatas memiliki beberapa bagian blok, setiap bagian blok berfungsi untuk menjadikan tegangan yang semula 220 Volt menjadi 5 - 12 Volt. Penjelasan setiap blok sebagai berikut:

1. Blok pertama terdapat komponen elektronika yang bernama transformator. Transformator berfungsi sebagai penurun tegangan dari 220 Volt menjadi 5- 12 Volt. Transformstor ini memiliki dua sisi, satu sisi berfungsi untuk menerima inputan yang dihasilkan dari PLN yang kemudian diteruskan melewati sebuah lilitan kuningan menuju ke sisi yang lain dimana terdapat beberapa varian output DC 5,10 dan 12 Volt.

2. Blok kedua terdapat sebuah komponen elektronika yang bernama diode bridge rectifier yang berfungsi sebagai penyearah tegangan AC menjadi DC.

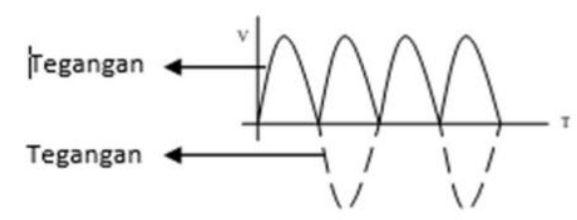

Sumber : Aprianto (2015)

Gambar III.3. Sinyal Penyearah Dioda

3. Blok ketiga terdapat sebuah komponen elektronika yang bernama kapasitor elektrolit berfungsi sebagai penyimpan tegangan yang telah berubah menjadi tegangan DC. Dari blok kedua yang telah disearahkan oleh diode bridge, kemudian disimpan oleh kaasitor untuk meminimalisir tingkat riple yang dihasikan. 


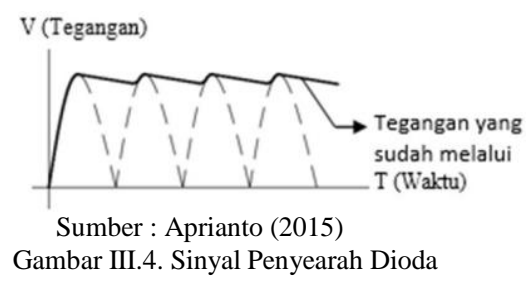

4. Blok keempat terdapat sebuah komponen elektronika yang bernama IC regulator yang berfungsi sebagai penstabil tegangan. IC regulator memiliki dua jenis yaitu penstabil tegangan positif dan penstabil negatif. Blok keempat ini menjadikan tegangan DC lebih stabil sesuai dengan IC regulator yang digunakan dengan rentang $5-12$ Volt.

\section{Perencanaan Input}

Perencanaan Sensor, Penulis menggunakan sensor infrared sebagai input untuk mengaktifkan LED, buzzer dan motorservo karena sensor infrared berfungsi sebagai sensor yang mampu mendeteksi garis hitam atau putih. Garis hitam memiliki value sama dengan 1, sedangkan garis putih memiliki value sama dengan 0 . Penulis menggunakan sensor infrared sebanyak 2 buah, sensor infrared membutuhkan daya sebesar

3.3 Volt untuk bisa beroperasi secara baik. Kemudian Penulis menghubungkan sensor infrared ke pin 2 dan 3 pada Arduino Uno [10].

\section{Perencanaan Proses}

Perencanaan Mikrokontroler, Pada bagian perencanaan mikrokontroller, penulis menggunakan mikrokontroller Arduino Uno sebagai otak dari semua sistem yang penulis rancang. Arduino Uno memiliki beberapa pin diantaranya pin input sebagai daya 3.3 Volt, 5 Volt, pin Ground, pin analog untuk menerima data sensor berupa data analog selain dari 1 dan 0 , pin digital untuk menerima data dengan value 1 dan 0 . Nantinya penulis menggunakan 2 pin digital untuk sensor Infrared, 2 pin digital untuk LED, 1 pin digital untuk buzzer dan 1 pin digital untuk motor Servo.

\section{E. Perencanaan Output}

Perencanaan LED, Buzzer, motor Servo dan LCD Display, Pada bagian perencanaan output, penulis menggunakan LED, Buzzer dan motor Servo sebagai indikator ketika data yang dikirimkan oleh sensor infrared sesuai dengan yang telah ditentukan dikontruksi coding. Penulis menggunakan 2 buah led, 1 buah buzzer dan 1 buah motor Servo sebagai indikator ketika sensor mendeteksi objek.

Penulis menghubungkan LED ke pin 4 dan 5, buzzer ke pin 6 dan motor Servo ke pin 9 pada mikrokontroller Arduino Uno. Led memiliki 2 kaki terdiri dari kaki positif dan negatif, pin positif dihubungkan ke pin Arduino Uno sedangkan pin negatif dihubungkan ke pin Ground pada Arduino Uno. Kemudian buzzer memiliki 2 kaki seperti led, yaitu kaki positif dan negatif, kaki positif dihubungkan ke pin digital Arduino Uno dan kaki negatif dihubungkan ke pin ground Arduino Uno. Terakhir, motor servo memiliki 3 kaki, yaitu kaki positif, negatif dan data. Kaki positif dihubungkan ke pin 5 volt Arduino Uno, kaki negatif dihubungkan ke pin ground Arduino Uno dan kaki data dihubungkan ke pin digital Arduino Uno.
F. Rangkaian Keseluruhan

1. Skematik Diagram

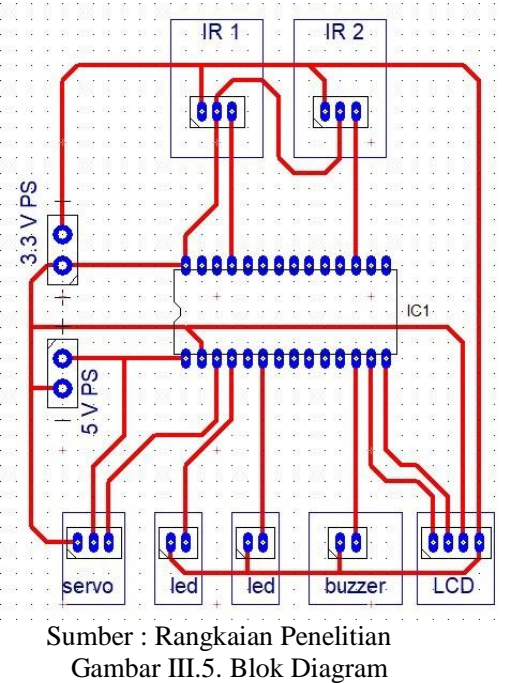

G. Perencanaan Program

1. Flowchart Program

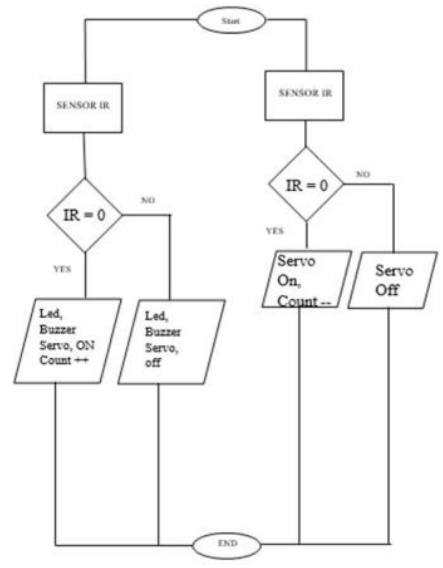

Gambar III.6. Flowchart

H. Pengujian

1. Tujuan Pengujian

Tujuan dari pengujian alat prototype count object adalah sebagai berikut :

a. Untuk mengetahui value atau nilai dari sensor infrared ketika mendeteksi objek maupun tidak mendeteksi objek.

b. Untuk memastikan setiap komponen dari komponen input, proses dan output berfungsi dengan baik ketika dilakukan pengujian.

c. Untuk mendapatkan nilai kestabilan dari sensor infrared.

d. Untuk mengetahui pengaruh dari prototype count object ini dalam membantu kebijakan dari pemerintah terkait pembatasan jumlah orang didalam suatu ruangan.

2. Langkah-Langkah Pengujian

Langkah-langkah pengujian adalah sebagai berikut :

a. Sebelum melakukan pengujian pastikan bahwa setiap komponen input, proses dan output saling terhubung satu sama lain. 
b. Periksa kabel yang menghubungkan sensor, Arduino Uno, led, buzzer dan motor servo.

c. Pastikan daya sudah terpasang ke mikrokontroller Arduino Uno.

d. Dekatkan objek kepada sensor yang sudah terpsang dibagian luar ruangan, ketika sensor infrared mendeteksi objek maka value dari sensor adalah 0 , maka led yang berwarna hijau akan menyala, motor servo akan bergerak dan buzzer akan berbunyi. Pada saat itu juga variable counter menghitung jumlah objek yang terdeteksi dan akan ditampilkan melalui LCD 16x2 yang sudah terpasang.

e. Selain sensor yang terletak diluar ruangan, penulis juga meletakkan sensor dibagian dalam ruangan untuk mendeteksi objek yang keluar dari ruangan tersebut. Apabila sensor ini mendeteksi objek yang keluar maka otomatis variable counter juga berkurang dan akan ditampilkan melalui LCD 16x2 yang sudah terpasang.

f. Apabila variable counter sudah mencapai batas maksimum dari jumlah objek yang harus ada didalam ruangan, maka led yang berwarna merah akan menyala dan buzzer akan berbunyi.

I. Hasil Pengujian

1. Pengujian Catu Daya

Sensor, mikrokontroller dan output yang digunakan membutuhkan catu daya yang berbeda-beda. Karena didalam sensor dan mikrokontroller menggunakan komponen-komponen dalam kategori arus lemah. Sensor Infrared, LED, buzzer membutuhkan daya sebesar tidak lebih dari 3 volt dan mendapat supply dari pin yang ada pada Mikrokontroller Arduin Uno. untuk motor servo dan LCD Display membutuhkan daya sebesar 5 volt dan mendapat supply dari pin yang ada pin mikrokontroller Arduino Uno. Hasil dari pengujian catu daya secara keseluruhan berfungsi dengan baik.

2. Pengujian Input

Hasil dari pengujian input didapatkan kesimpulan bahwa ketika sensor infrared mendeteksi objek maka sensor bernilai 0 dan ketika sensor tidak mendeteksi objek bernilai 1, artinya sensor berfungsi dengan baik karena ada perbedaan dari dua kondisi sehingga bisa sebagai trigger untuk menjalankan output yang digunakan Gambar dibawah ini memperlihatkan hasil pembacaan sensor ketika mendeteksi objek dan sebaliknya yang ditampilan melalui serial monitor pada Software Arduino IDE.

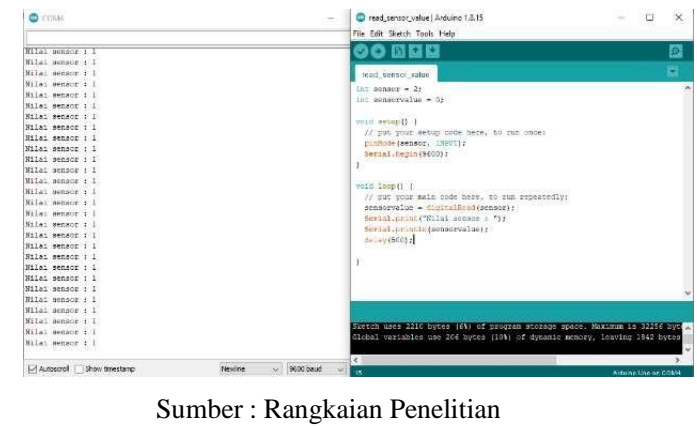

Gambar IV.1. Nilai Sensor IR ketika mendeteksi Objek

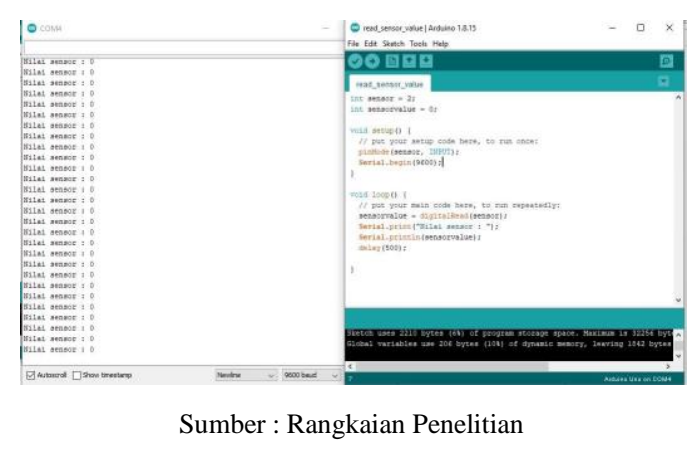

Gambar IV.2. Nilai Sensor IR ketika tidak mendeteksi Objek

3. Pengujian Proses

Hasil dari pengujian proses, dalam hal ini mikrokontroller Arduino Uno berfungsi dengan baik selama pengujian berlangsung. Selama pengujian belrangsung tidak terjadi masalah terhadap kinerja mikrokontroller. Hal yang perlu diperhatikan lebih banyak kepada aspek pengetahuan dasar pemrograman yang dipakai untuk menggunakan Arduino Uno, yaitu dasar c++. Hal yang umum digunakan seperti penamaan variable yang Case Sensitive, penggunaan semicolone, penggunaan operator perbanding seperti < (lebih kecil), <= (lebih kecil atau sama dengan, > (lebih besar), >= (lebih besar atau sama dengan), == (sama dengan), penggunaan percabangan (Iff .. Else ..), perulangan (for.. loop), dan lain-lain.

4. Pengujian Output

Hasil dari pengujian output komponen seperti led dan buzzer berfungsi dengan baik, yang menjadi perubahan adalah dibaris coding seperti harus mengganti waktu delay supaya led menyala dan buzzer berbunyi sesuai yang diinginkan, led hijau menyala sepersekian detik yaitu 0,2 detik kemudian mati kembali, sedangkan buzzer berbunyi selama 0,3 detik kemudian mati kembali. Kemudian lampu merah menyala ketika jumlah objek sudah terpenuhi didalam satu ruangan. Selain led dan buzzer, output LCD display berfungsi dengan baik yaitu siap digunakan. Hal yang perlu diperhatikan yaitu dibaris coding, karena harus diganti beberapa kali sampai LCD mampu memberikan informasi yang diinginkan, yaitu menampilkan jumlah object didalam satu ruangan. Output terakhir yaitu penggunaan motor Servo untuk menggerakan prototype pintu dan motor servo berfungsi dengan baik.

5. Analisa Hasil

Hasil dari pengujian prototype object count secara keseluruhan berfungsi dengan baik. Hal yang paling banyak dirubah yaitu dari segi baris coding yang dibuat oleh penulis, karena beberapa kali harus dirubah seperti harus delay berapa lama untuk menyalakan led dan buzzer, memberikan nilai yang tepat kepada motor servo agar gerakan motor sesuai yang diharapkan, kondisi pengkondisian yang tepat untuk mengaktifkan led, buzzer, motor dan mengatur tampilan yang akan ditampilkan didalam LCD Display.

Untuk memperoleh hasil yang optimal dari pengujian prototype ini adalah : 
a. Memastikan setiap kabel terhubung dari satu komponen ke komponen yang lain sesuai dengan rangkaian yang telah dibuat dan pemasangan kabel ke pin project board, komponen output dan sensor harus pas.

b. Memperhatikan keadaan sekitar seperti cahaya ruangan baik didalam dan diluar ruangan yang mempengaruhi dalam mendapatkan nilai sensor untuk hasil output yang maksimal.

c. Usia dari setiap komponen yang mempengaruhi kinerja alat secara keseluruhan.

d. Mengecek terlebih dahulu setiap komponen yang akan digunakan.

\section{KESIMPULAN}

Dari hasil perancangan, pembuatan, pengujian dan analisa dapat disimpulkan sebagai berikut : Prototype Object Counter sebagai langkah awal untuk membuat sebuah system yang berbasis automated system secara real diberbagai bidang seperti perhotelan instansi dan lain-lain. Karena menggunakan sensor infrared, intensitas cahaya mempengaruhi nilai dari sensor tersebut. Kebijakan pemerintah terkait jumlah maksimal yang ada didalam suatu ruangan, Prototype Object Counter ini mampu membantu kebijakan tersebut Selain membantu kebijakan pemerintah, harapannya penurunan jumlah angka yang terinfeksi covid-19 bisa tercapai.

\section{REFERENSI}

[1] Daud, Anwar, Aminuddin Syam, Arsunan Arsin dan Sudirman Sanuddin Hanafiah. 2020. Penanganan Coronavirus (Covid-19) Ditinjau dari Perspektif Kesehatan Masyarakat. Yogyakarta : Gosyen Publishing.

[2] Muhyiddin. (Juni 2020). The Indonesian Journal of Development Planning VolumeIV No. 2 -Juni 2020. Covid-19,New Normal dan Perencanaan Pembangunan diIndonesia, 240-252.

[3] Kementrian Keuangan Republik Indonesia "Merekam Pandemi Covid19 dan Memahami Kerja Keras PengawalAPBN"

https://www.kemenkeu.go.id/media/18295/buku- merekampandemi-covid-19-dan-memahami-kerja-keras-pengawalapbn.pdf (31 Mei 2021)

[4] Keputusan Menteri Kesehatan Republik Indonesia Nomor HK.01.07/MENKES/382/2020 Tentang Protokol Kesehatan Bagi Masyarakat di Tempat dan Fasilitas Umum dalam Rangka Pencegahan dan Pengendalian Corona Virus Disease 2019 (Covid-a9). http://hukor.kemkes.go.id/uploads/produk_hukum/KMK

_No HK_01_07-MENKES-382

2020_ttg_Protokol_Kesehatan_Bagi_Masyarakat_di_Tempat_dan_Fasi litas_Umum_Dalam_Rangka_Pencegahan_COVID-19.pdf. (19 Juni 2020)
[5] Kadir, A. (2016). Simulasi Arduino. Jakarta: PT Elex Media Komputindo.

[6] Informatika STMIK Antar Bangsa Vol. 7 No. 1. Februari2021 : 1$8 . \quad$ Diambil dari https://ejournal.antarbangsa.ac.id/index.php/jti/article/view/345. (5 Mei 2021).

[7] Informatika STMIK Antar Bangsa Vol. 7 No. 1. Februari 2021 : 1622. Diambil dari https://ejournal.antarbangsa.ac.id/jti/article/view/347/316.(5 Mei 2021)

[8] David Mellis. 2020. Language Reference Diambil dari https://www.arduino.cc/reference/en/. (13 Juli 2020).

[9] Wicaksono, Mochamad Fajar. 2019. Aplikasi Arduino dan Sensor. Bandung : Informatika Bandung.

[10] Rokhmah, Nida Nur. 2018. Kendali Kecepatan Motor DC Dengan Metode PID Berbasis Arduino Uno. Teknik Elektro dan Vaksional.

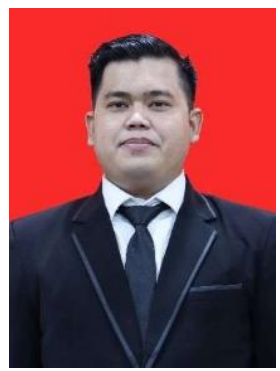

Arif Fadli, lahir pada tanggal 29November 1997 Tahun 2021 lulus dari Program Strata Satu (S1) Program Studi Teknik Informatika di STMIK Antar Bangsa.

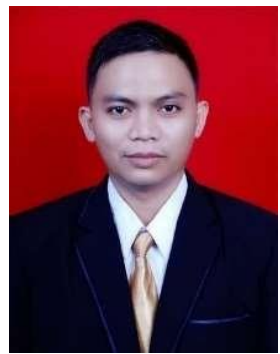

Subhiyanto, lahir di Brebes pada tanggal 10 Maret 1984.Tahun 2012 Lulus Sarjana KomputerJurusan Teknik Informatika di STMIK Nusa Mandiri. Tahun 2020 lulus program Pasca Sarjana Ilmu Komputer dengan konsentrasiRekayasa Komputasi Terapan di Universitas Budi Luhur. Saat ini aktif mengajar sebagai dosen tetap dan sebagai Kepala Biro TeknologiInformasi di STMIK Antar Bangsa 